\title{
Toxicity and lethal effects of herbaceous plant crude extracts against Spodoptera litura
}

\author{
Divyansh Singh ${ }^{1}$ and Kiran Gandhi Bapatla $2^{2^{*}}$
}

\begin{abstract}
Background: Tobacco caterpillar, Spodoptera litura, attacks various cultivated plants and causes significant yield losses. In this study, an eco-friendly approach like using botanical insecticides was adopted to examine the toxicological effect of six herbaceous plants (Phyllanthus niruri, Cyperus rotundus, Euphorbia hirta, Boerhavia diffusa, Parthenium hysterophorus and Cynodon dactylon) against S. litura.

Results: Six herbaceous plants crude extract showed a definite level of toxicity against S. litura larvae (3rd instar) using the surface diet contamination method. Among tested herbaceous plants crude extract at $5 \mu \mathrm{g} / \mathrm{ml}$ concentration, C. dactylon showed significant high larval mortality (75\%) against S. litura larvae compared to P. niruri (39\%), C. rotundus (36\%), P. hysterophorus (26\%), B. diffusa (22\%) and E. hirta (22\%) treatments. A cent percent S. litura larval mortality was achieved at lower concentration from crude extract of $C$. dactylon $(11.2 \mu \mathrm{g} / \mathrm{ml})$ compared to $E$. hirta $(18.6 \mu \mathrm{g} / \mathrm{ml})$, B. diffusa $(24.39 \mu \mathrm{g} / \mathrm{ml})$, P. hysterophorus $(31.4 \mu \mathrm{g} / \mathrm{ml})$ crude extracts. The lethal concentration ( $\left(\mathrm{C}_{50}\right)$ of $C$. dactylon, P. hysterophorus, C. rotundus, P. niruri, B. diffusa and E. hirta crude extracts was estimated to be 1.45, 4.09, 5.74, $6.75,10.92$ and $13.62 \mu \mathrm{g} / \mathrm{ml}$, respectively.
\end{abstract}

Conclusion: The study results suggested that $C$. dactylon crude extract possesses the potential to reduce the $S$. litura damage on crops as a natural alternative to the chemical insecticides with no toxicity to beneficial species.

Keywords: Cynodon dactylon, Discriminating dose, Ethyl acetate, Insecticidal, Larvicidal

\section{Background}

Insect pest damage is one of the major reasons for enormous field crop losses. Tobacco cutworm, Spodoptera litura (Fabricius) (Lepidoptera: Noctuidae), is a serious polyphagous insect pest that damages around 115 plant species (Atwal \& Dhaliwal, 2009). Out of 115 globally recorded host plants of $S$. litura, 60 are known from India (Garad et al., 1984). During 2008-09, an outbreak of $S$. litura on soybean in Rajasthan and Maharashtra states of India caused losses up to 64 million and 300 million USD, respectively (Dhaliwal \& Koul, 2010). To prevent crop losses, the application of chemical insecticides is the most adopted pest management strategy; however,

\footnotetext{
*Correspondence: kiran.bapatla@icar.gov.in; bkg0530@gmail.com

${ }^{2}$ Division of Crop Protection, ICAR-Indian Institute of Pulses Research,

Kanpur, U.P., India

Full list of author information is available at the end of the article
}

improper use of insecticides in many nations results in insecticides resistance (Vasantha-Srinivasan et al., 2017). Insecticide pest resistance to different synthetic insecticides is a growing problem, and field-level resistance of $S$. litura against insecticides was reported by Gandhi et al. (2016) and Senthil-Nathan (2013). Present limitations associated with the insecticides necessitated for searching selective and eco-friendly insecticides.

Botanical insecticides are instrumental in the discovery and development of synthetic chemical products. Thus, continued discovery and development of botanical-based products exemplify the direction for designing new and better pesticides (Senthil-Nathan, 2013). Phyllanthus niruri mostly found in the tropical and subtropical regions has a long history in the traditional medicinal system to prevent or treat various diseases (Bagalkotkar et al., 2006). Cyperus rotundus spread in temperate, tropical and sub-tropical regions 
of the world (Nagarajan et al., 2015), and its essential oil affects the insect pest behavior (Zandi-Sohani \& Ramezani, 2015). Euphorbia hirta extracts showed a broad range of biological properties, including antimicrobial, antifungal, anti-inflammatory, antioxidant, anticancer and antidiabetic activities (Almosnid et al., 2018). Boerhavia diffusa is used in traditional medicine for the treatment of diabetes, stress, dyspepsia, abdominal pain, inflammation, jaundice, enlargement of spleen, heart diseases, bacterial infections and impotence (Nalamolu et al., 2004). Parthenium hysterophorus is used in the treatment of skin diseases, malaria, rheumatism and headache (Raghu et al., 2014). Cynodon dactylon possesses various medicinal properties such as antiviral, antimicrobial (Dhar et al., 1968), antiinflammatory (Biswas \& Mukherjee, 2003) and immunomodulatory activity (Santhi \& Annapoorani, 2010).

Talukder and Miyata (2002) reported plant-derived materials are safe to natural enemies, compatible with biological control agents for Integrated Pest Management (IPM) and non-toxic to the environment. Plant products can be easily produced by farmers in smallscale industries and are less expensive (Talukder \& Howse, 1995). Therefore, a century-old practice of protecting crops using plant derivatives, which are known to resist insect attack (Ewete et al., 1996) is considered in this study and planned an in vitro evaluation of dosedependent toxicity of $P$. niruri, C. rotundus, E. hirta, $B$. diffusa, P. hysterophorus and C. dactylon crude extract against $S$. litura larvae.

\section{Methods \\ Collection and extraction of phytochemicals from herbaceous plants}

Six different herbaceous plants were collected (entire plant with intact roots) from legumes growing fields (Fig. 1). A weed scientist from the Indian Institute of Pulses Research, Kanpur (Dr. Chaitanya Prasad Nath) identified the herbs up to species viz., $P$. niruri, C. rotundus, E. hirta, B. diffusa, P. hysterophorus and C. dactylon. Since these are commonly available and well characterized herbs the specimens were not submitted to the repository. In this experiment, heat energy was used to rupture the cell membrane and extract the thermostable bio-compounds from different herbaceous plants. One kilogram (wet weight) of each herbaceous plant was brought to the laboratory in a collection bag; shade dried for a week to remove the moisture from the plant parts. The moisture free herbaceous plants were grinded to powder and stored in PVC bottles at $28 \pm 2{ }^{\circ} \mathrm{C}$. The respective herbaceous plant ( $P$. niruri-10 g, C. rotundus-10 g, E. hirta-10 g, B. diffusa-10 g, P. hysterophorus $-10 \mathrm{~g}$ and $C$. dactylon-5 g) was weighed in flat bottom round flask along with $50 \mathrm{ml}$ of organic solvent Ethyl Acetate (EtoAc). The contents of the flask were alternatively heated (flasks placed in a hot water bath at $100{ }^{\circ} \mathrm{C}$ ) and agitated (flasks placed in an orbital shaker

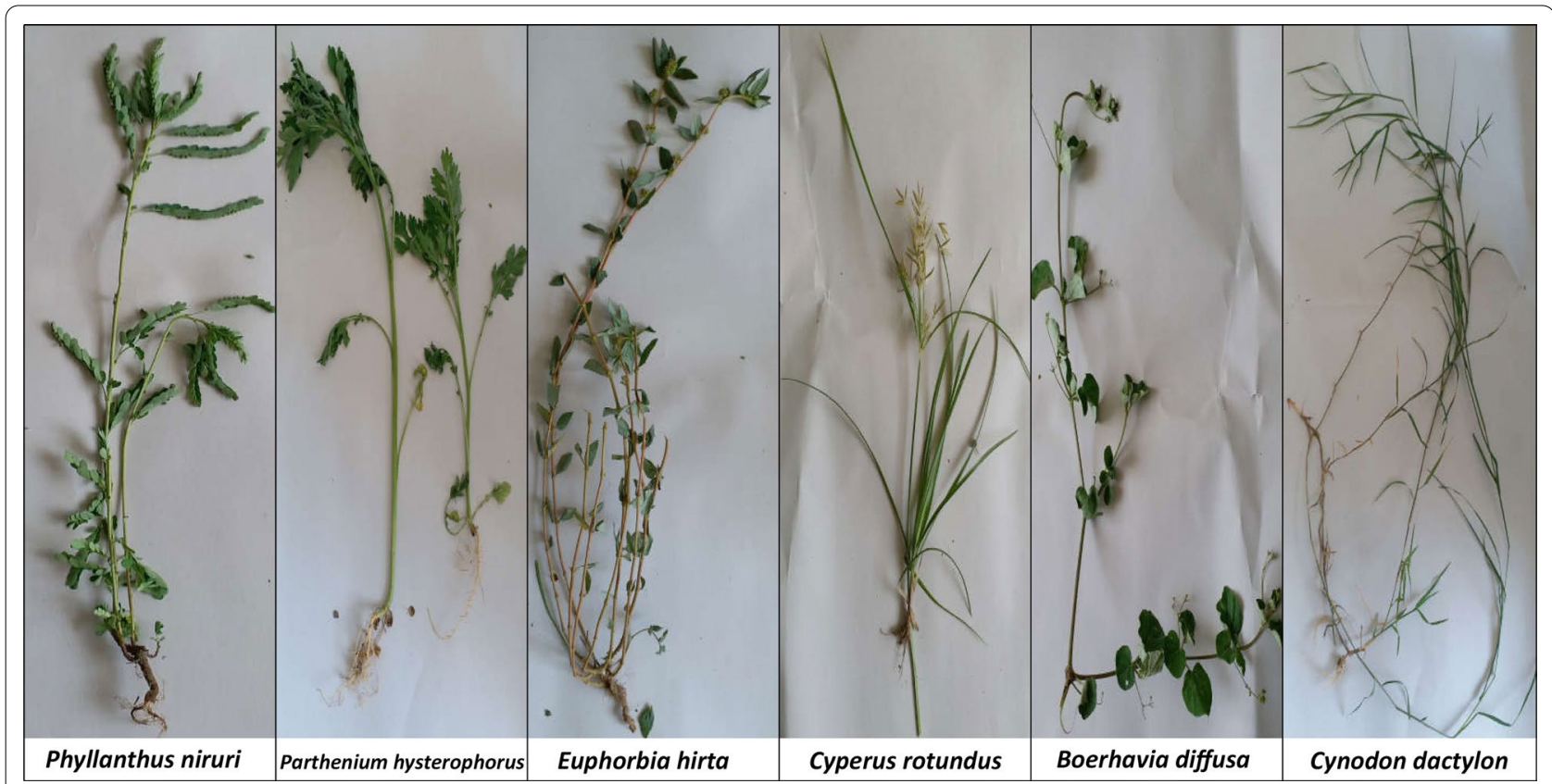

Fig. 1 Herbaceous plants used for crude extraction 
at $150 \mathrm{rpm}$ for $2 \mathrm{~h}$ ). The heating and agitating step were repeated thrice. The filtrate (organic phase) was collected by passing the contents in the flasks through Whatmanno.1 filter paper. The filtrate was air-dried $(24 \mathrm{~h})$ in a glass petri plate, and the remaining residue was suspended in 5-8 $\mathrm{ml}$ of Methanol $(\mathrm{MeOH})$. Subsequently, the filtrate was passed through a $0.45 \mu$ syringe filter to remove the macroparticles from the crude extract. The crude extract of each herbaceous plant was stored at $8^{\circ} \mathrm{C}$ for the bioassay experiment. Aforesaid protocol for extraction of bioactive compounds from herbaceous plants against lepidopteran insect pests was developed and standardized in this study. Crude extract appearance and percent yield (i.e., estimated by comparing mass of crude extract to the mass of fresh material) of individual herbaceous plants are presented in Table 1.

\section{Insect rearing}

Test insect, Spodoptera litura, was procured from live insect repository of National Bureau of Agricultural Important Insects, Bengaluru, India, that was reared according to Bapatla et al. (2021). Obtained S. litura pupae were placed in a glass container for adult emergence. Emerged adult moths were released in a glass container $(15 \mathrm{~cm}$ diameter and $25 \mathrm{~cm}$ height) for mating, which was provided with paper sheets for oviposition and cotton swab with $20 \%$ honey solution as a source of food to adult moths. From oviposition within 3-4 days, eggs were hatched to neonates that are reared on tender castor leaves for initial 12 days. Subsequently, larvae were individually reared in 12 well insect culture plates on the semi-synthetic diet (chickpea flour-100 g, methyl- $p$ - hydroxybenzoate sodium salt-2 g, 2,4-hexadecenoic acid-1 g, yeast extract powder-10 g, agaragar-12.75 g, L-Ascorbic acid-3.25 g, multivitamin-2 capsules, vitamin E-2 capsules, Streptomycin -0.25 g, $10 \%$, formaldehyde $-5 \mathrm{ml}$, distilled water $-780 \mathrm{ml}$ ) until pupation (14-16 days) (Babu et al., 2014). Within 10-12 days adults emerged from the pupa and the biological life cycle (35-40 days) was continued. Test insect was reared in an incubator at $28 \pm 1{ }^{\circ} \mathrm{C}$ temperature, $70 \pm 2 \%$ relative humidity and 14:10 light and dark period for six generations in the laboratory and, further generations were used in bioassay experiments.

\section{Toxicity of herbaceous plant crude extracts}

Oral toxicity of the crude extracts of herbaceous plants was evaluated against third instar larvae of S. litura using the surface contamination method (Micheal et al., 1997). Initially, a semi-synthetic diet was prepared and poured $(3 \mathrm{ml})$ into each well of 12 well insect rearing plates. Later, $100 \mu \mathrm{l}$ of crude extract from each herbaceous plant was applied to the diet surface $\left(3.8 \mathrm{~cm}^{2}\right)$ in each well and swirled the plate to ensure a uniform spread of the extract over the diet. The surface of the diet was allowed to dry in an aseptic condition for three hours to evaporate the solvent residue. Simultaneously, the diet surface was also treated with distilled water (control), $\mathrm{MeOH}$ (negative control) and Flubendiamide 39.35SC (positive control) separately. On to the treated surface of the diet, healthy (active), equal-sized (3rd instar) and pre-starved $(2 \mathrm{~h})$ test insect larvae were released individually. Each treatment was replicated thrice with ten larvae per replication. The same set of experiments was repeated in three episodes. Larval mortality was taken on every day for three days. Larvae showing moribund symptoms were also considered dead larvae. The number of dead larvae on $72 \mathrm{~h}$ after treatment were considered as final larval mortality and presented as percent larval mortality. The experiment was conducted at $28^{\circ} \mathrm{C} \pm 2^{\circ} \mathrm{C}$ and $70 \pm 2 \%$ temperature and relative humidity, respectively.

\section{Lethal toxicity of herbaceous plant extracts}

To find out the toxic concentration of each herbaceous plant extract a range-finding test was conducted (at which $20-80 \%$ larval mortality can be achieved). For this initially, $5 \mu \mathrm{g} / \mathrm{ml}$ concentration of all herbaceous plant extracts was tested and observed larval mortality. Based

Table 1 Yield of crude extract and appearance of six herbaceous plants

\begin{tabular}{|c|c|c|c|c|c|c|}
\hline Herbaceous plant & $\begin{array}{l}\text { Fresh } \\
\text { material } \\
\text { mass }(g)\end{array}$ & $\begin{array}{l}\text { Crude extract } \\
\text { mass }(\mu \mathrm{g})\end{array}$ & $\mathrm{MeOH}(\mathrm{ml})$ & $\begin{array}{l}\text { Concentration of } \\
\text { crude extract }(\mu \mathrm{g} / \mathrm{ml})\end{array}$ & $\begin{array}{l}\text { Percent yield of } \\
\text { crude extract } \\
(\% \mathrm{w} / \mathrm{w})\end{array}$ & Appearance* \\
\hline Phyllanthus niruri & 10 & 100 & 5 & 20 & $1 \times 10^{-5}$ & Olive gum \\
\hline Cyperus rotundus & 10 & 120 & 8 & 15 & $12 \times 10^{-6}$ & Olive gum \\
\hline Euphorbia hirta & 10 & 100 & 5 & 20 & $1 \times 10^{-5}$ & Olive green gum \\
\hline Boerhavia diffusa & 10 & 275 & 5 & 55 & $275 \times 10^{-7}$ & Olive brown semisolid \\
\hline Parthenium hysterophorus & 10 & 175 & 5 & 35 & $175 \times 10^{-7}$ & Dark green gums \\
\hline Cynodon dactylon & 5 & 75 & 5 & 15 & $15 \times 10^{-6}$ & Bluish green gum \\
\hline
\end{tabular}

*Inter-Society Color Council-National Bureau of Standard (ISCC-NBS), MeOH methanol 
on larval mortality at $5 \mu \mathrm{g} / \mathrm{ml}$ concentration, further, five concentrations were adjusted until the targeted $20-80 \%$ larval mortality was achieved. Five lethal concentrations were estimated for $P$. niruri $(0.72,2.43,6.08,12.16$, $15.0 \mu \mathrm{g} / \mathrm{ml})$, C. rotundus (0.66, 2.21, 5.54, $11.09,13.87 \mu \mathrm{g} /$ $\mathrm{ml})$, E. hirta (12.31, 13.98, 15.66, 16.74, $18.6 \mu \mathrm{g} / \mathrm{ml}), B$. diffusa $(7.27,11.55,15.83,20.11,24.39 \mu \mathrm{g} / \mathrm{ml}), P$. hysterophorus $(1.5,5.02,12.56,25.12,31.4 \mu \mathrm{g} / \mathrm{ml})$ and $C$. dactylon $(0.6,2.01,5.04,10.08,11.2 \mu \mathrm{g} / \mathrm{ml})$ extracts against $S$. litura larvae, respectively. Each treatment was replicated thrice with ten larvae per replication. Larval mortality was taken on every day for three days, and after $72 \mathrm{~h}$ final larval mortality was considered.

\section{Statistical analysis}

Descriptive statistics showed percent larval mortality data was positively skewed (1.434). Therefore, the data were transformed $\left(\log _{10}\right)$ to reduce the skewness to 0.903 , i.e., within the range (from -1 to +1$)$. The transformed data were used for conducting a One way analysis of variance (ANOVA) to observe the significant differences $(p \leq 0.05)$ between treatments using SPSS software ver.25. Percent larval mortality data in Table 2 were shown in mean \pm standard deviation format. The mean of ranks for percent larval mortality attained by crude extracts, water and methanol were compared using Tukey's HSD post hoc test. To estimate the lethal concentrations of crude extracts from herbaceous plants, probit analysis was carried out using SPSS software ver.25 (IBM Corp., 2017).

\section{Results}

\section{Crude extract from herbaceous plants}

The maximum yield of crude extract was obtained from B. diffusa $(275 \mu \mathrm{g})$, followed by P. hysterophorus $(175 \mu \mathrm{g})$, C. rotundus $(120 \mu \mathrm{g})$, P. niruri $(100 \mu \mathrm{g})$, E. hirta $(100 \mu \mathrm{g})$ and $C$. dactylon $(75 \mu \mathrm{g})$. The concentration of crude extract from B. diffusa, P. hysterophorus, C. rotundus, $P$. niruri, E. hirta and C. dactylon was estimated to be 20, $15,20,55,35$ and $15 \mu \mathrm{g} / \mathrm{ml}$ by dissolving the semisolid or gum type crude extract with $\mathrm{MeOH}$, respectively. Crude extracts from $P$. niruri and $C$. rotundus are olive in color, whereas $E$. hirta, B. diffusa, P. hysterophorus and C. dactylon extracts were olive green, olive-brown, dark green and bluish green colors, respectively (Table 1 ).

\section{Toxicity of herbaceous plant extracts}

One way ANOVA table $[F(6,29)=383.84, p<0.05]$ revealed statistically significant differences for $S$. litura larval mortality between herbaceous plants crude extracts at $5 \mu \mathrm{g} / \mathrm{ml}$ concentration. Larval mortality ranged from 22 to $90 \%$; whereas $\mathrm{MeOH}$ and water treatments showed no larval mortality. The insecticide flubendiamide $39.35 \mathrm{SC}$ treatment resulted in 90\% highest and significant larval mortality. Among herbaceous extracts, Cynodon dactylon crude extract showed significant and higher S. litura larval mortality (75\%). The S. litura larval mortality from P. niruri (39\%) and C. rotundus (36\%) crude extracts were statistically at par; whereas, $P$ hysterophorus crude extract resulted in only $26 \%$ larval mortality and significant from other treatments. Lower S. litura larval mortality (22\%) was noticed from $E$. hirta and $B$. diffusa crude extract (Table 2).

\section{Lethal concentrations of crude extracts}

Based on range-finding test results five different lethal concentrations of six herbaceous plants crude extract were tested against 3 rd instar larvae of S. litura. Five concentrations $(15.2,12.16,6.08,2.43$ and $0.72 \mu \mathrm{g} / \mathrm{ml})$ of crude extract from $P$. niruri resulted in $80.00,60.00$, 46.67, 23.33 and 3.33 percent S. litura larval mortality, respectively. The crude extract concentrations from $C$. rotundus $(13.81,11.09,5.54,2.21$ and $0.66 \mu \mathrm{g} / \mathrm{ml})$ resulted in $80.00,70.00,40.00,20.00$ and 10.00 percent S. litura larval mortality, respectively. Similarly, 100.00, 80.00,

Table 2 Toxicity of crude extracts of herbaceous plants against Spodoptera litura larvae

\begin{tabular}{llll}
\hline Herbaceous plants & Concentration $(\boldsymbol{\mu g} / \mathbf{m l})$ & Dosage $\left(\boldsymbol{\mu l} / \mathbf{3 . 8} \mathbf{c m}^{\mathbf{2}}\right)$ & Larval mortality $(\%)$ \\
\hline Phyllanthus niruri & 5 & 100 & $39 \pm 1.00^{\mathrm{b}}(1.59)$ \\
Cyperus rotundus & 5 & 100 & $36 \pm 1.00^{\mathrm{b}}(1.56)$ \\
Euphorbia hirta & 5 & 100 & $22 \pm 0.58^{\mathrm{d}}(1.34)$ \\
Boerhavia diffusa & 5 & 100 & $22 \pm 1.53^{\mathrm{d}}(1.35)$ \\
Parthenium hysterophorus & 5 & 100 & $26 \pm 1.53^{\mathrm{c}}(1.42)$ \\
Cynodon dactylon & 5 & 100 & $75 \pm 1.00^{\mathrm{a}}(1.88)$ \\
Methanol (99.9\%) & & 100 & $0^{\mathrm{e}}$ \\
Control (autoclaved water) & & 100 & $0^{\mathrm{e}}$ \\
S.Em \pm & & & 0.04506 \\
Variance & & & 0.037
\end{tabular}

Values in parenthesis are $\log _{10}$ transformed values and means values followed by same letter are significant with each other 
70.00, 56.67 and 33.33 percent $S$. litura larval mortality was observed at 18.6, 16.74, 15.66, 13.98 and $12.31 \mu \mathrm{g} / \mathrm{ml}$ crude extract concentrations from $E$. hirta, respectively. Boerhavia diffusa crude extract at 24.39, 20.11, 15.83, 11.55 and $7.27 \mu \mathrm{g} / \mathrm{ml}$ concentrations showed 100.00 , 93.33, 70.00, 56.67 and 20.00 percent $S$. litura larval mortality, respectively. Five concentrations (31.4, 25.12, 12.56, 5.02 and $1.5 \mu \mathrm{g} / \mathrm{ml}$ ) from $P$. hysterophorus crude extract demonstrated 100.00, 80.00, 66.67, 50.00 and 33.33 percent $S$. litura larval mortality, respectively. Larva of $S$. litura showed 100.00, 86.67, 76.67, 50.00 and 33.33 percent mortality when treated with different concentrations of $C$. dactylon crude extract like 11.2, 10.08, 5.04, 2.01 and $0.6 \mu \mathrm{g} / \mathrm{ml}$, respectively. Though E. hirta $(18.6 \mu \mathrm{g} / \mathrm{ml})$, B. diffusa $(24.39 \mu \mathrm{g} / \mathrm{ml})$, P. hysterophorus $(31.4 \mu \mathrm{g} / \mathrm{ml})$ crude extracts provided $100 \%$ larval mortality, they are at higher concentrations compared to C. dactylon $(11.2 \mu \mathrm{g} /$ $\mathrm{ml})$.

Dose-response probit analyses envisaged a nine times differences in $\mathrm{LC}_{50}$ values between six herbaceous plant crude extracts against $S$. litura larvae. The lowest $\mathrm{LC}_{50}$ was shown by $C$. dactylon crude extract $(1.45 \mu \mathrm{g} / \mathrm{ml})$ followed by $P$. hysterophorus $(4.09 \mu \mathrm{g} / \mathrm{ml}), C$. rotundus $(5.74 \mu \mathrm{g} / \mathrm{ml})$, P. niruri $(6.75 \mu \mathrm{g} / \mathrm{ml})$, B. diffusa $(10.92 \mu \mathrm{g} /$ $\mathrm{ml})$ and $E$. hirta $(13.62 \mu \mathrm{g} / \mathrm{ml})$. Similarly, a five-time variation was observed between herbaceous plant extracts for $\mathrm{LC}_{99}$ values. The lower $\mathrm{LC}_{99}$ was observed from $E$. hirta $(21.56 \mu \mathrm{g} / \mathrm{ml})$ crude extract followed by $B$. diffusa $(30.31 \mu \mathrm{g} / \mathrm{ml})$, C. dactylon $(45.67 \mu \mathrm{g} / \mathrm{ml})$, P. niruri $(130.42 \mu \mathrm{g} / \mathrm{ml})$, C. rotundus $(143.34 \mu \mathrm{g} / \mathrm{ml})$ and P. hysterophorus $(213.91 \mu \mathrm{g} / \mathrm{ml})$ (Table 3$)$.

\section{Discussion}

At the international level incorporation of integrated pest management tactics using biopesticides is being encouraged (Edwin et al., 2016). The herbaceous plants, P. niruri, E. hirta, B. diffusa, P. hysterophorus and C. dactylon are well known for their diversified medicinal value and therapeutic uses (Dhar et al., 1968; Huang et al., 2012; Lim \& Murtijaya, 2007; Nalamolu et al., 2004; Raghu et al., 2014). Insecticidal action of $C$. dactylon and C. rotundus was reported against red flour beetle (Islam \& Talukder, 2005) and ants, aphids, flies and cockroaches (Bañez \& Castor, 2011), respectively; however, P. niruri, E. hirta, B. diffusa and P. hysterophorus plants were not studied for their insecticidal activity. Our study is the first to explore the larvicidal potential of crude extract from $P$. niruri, E. hirta, B. diffusa, C. rotundus, P. hysterophorus and $C$. dactylon against $S$. litura larvae. However, earlier studies showed plant families like Apiaceae (Roman Pavela \& Naděžda Vrchotová, 2013), Asteraceae (Ashokaraj \& Mahadev, 2012; Rathi \& Gopalakrishnan, 2006; Romo-Asunción et al., 2016), Lamiaceae (Romoasunción et al., 2016), Rutaceae (Arivoli \& Tennyson, 2013; Barakat, 2011; Kumar et al., 2014; Thodsare et al., 2014), Solanaceae (Jeyasankar \& Elumalai, 2012), Meliaceae (Dinesh-Kumar et al., 2018), Fabaceae (Bermúdez et al., 2009; Dang Hoa et al., 2017) and Lamiaceae (Rajput et al., 2018) demonstrated anti-larval and antifeedant activity against Spodoptera species.

In this study, $C$. dactylon crude EtoAc extract showed higher toxicity (75\% larval mortality) compared to other herbaceous plants, whereas Islam and Talukder (2005) reported water extract from C. dactylon showed only 37\% red flour beetle mortality. Following chemical constituents like cynodin, hydrocyanic acid, triticin, proteins, carboydrated and beta-carotene were reported from $C$. dactylon (George et al., 1997; Kao et al., 2005). Lopez (1903) reported hydrocyanic acid as an insecticidal, which might be attributed to the highest $S$. litura larval mortality from $C$. dactylon crude extract. Limited previous studies pressed us to compare the present results with the efficacy of other plant extracts against Spodoptera species. In the present study, $C$. dactylon crude extract at $0.0005 \%(5 \mu \mathrm{g} / \mathrm{ml})$ concentration showed $75 \%$ larval mortality of S. litura; however, $15 \%$ crude aqueous

Table 3 Lethal and sub-lethal toxicity of herbaceous extract against Spodoptera litura larvae

\begin{tabular}{|c|c|c|c|c|c|c|c|c|c|}
\hline \multirow[t]{2}{*}{ Herbaceous Plants } & \multirow[t]{2}{*}{$\mathrm{LC}_{50}(\mu \mathrm{g} / \mathrm{ml})$} & \multicolumn{2}{|c|}{$95 \%$ Confidence limits } & \multirow[t]{2}{*}{$\mathrm{LC}_{99}(\mu \mathrm{g} / \mathrm{ml})$} & \multirow{2}{*}{$\begin{array}{l}\text { Regression } \\
\text { equation } \\
(Y=a+b X)\end{array}$} & \multicolumn{3}{|l|}{ Fit of probit line } & \multirow[t]{2}{*}{$n$} \\
\hline & & Lower bound & Upper bound & & & $\begin{array}{l}\text { Heterogeneity } \\
\text { factor }\left(x^{2}\right)\end{array}$ & Slope ( \pm S.E) & $d f$ & \\
\hline Phyllanthus niruri & 6.75 & 5.01 & 9.27 & 130.42 & $Y=1.5+1.809 X$ & 1.55 & $1.809 \pm 0.296$ & 3 & 90 \\
\hline Cyperus rotundus & 5.74 & 4.18 & 8.07 & 143.34 & $Y=1.264+1.665 X$ & 2.843 & $1.665 \pm 0.271$ & 3 & 90 \\
\hline Euphorbia hirta & 13.62 & 12.72 & 14.27 & 21.56 & $Y=13.239+11.671 X$ & 3.196 & $11.671 \pm 2.071$ & 3 & 90 \\
\hline Boerhavia diffusa & 10.92 & 9.51 & 12.19 & 30.31 & $Y=5.451+5.249 X$ & 3.202 & $5.249 \pm 0.764$ & 3 & 90 \\
\hline $\begin{array}{l}\text { Parthenium hystero- } \\
\text { phorus }\end{array}$ & 4.09 & 2.313 & 6.063 & 213.91 & $Y=0.829+1.345 X$ & 6.425 & $1.354 \pm 0.242$ & 3 & 90 \\
\hline Cynodon dactylon & 1.45 & 0.87 & 2.09 & 45.67 & $Y=0.2551 .555 X$ & 4.877 & $1.555 \pm 0.256$ & 3 & 90 \\
\hline
\end{tabular}

$d f$ degree of freedom, $x^{2}$ values were not significant for all the assays 
leaf extract of Eupatorium triplinerve showed 92\% S. litura larval mortality (Ashokaraj \& Mahadev, 2012); Synedrella nodiflora showed $100 \%$ S. litura larval mortality (Rathi \& Gopalakrishnan, 2006); Senecio salignus $(500 \mu \mathrm{g} / \mathrm{ml})$ and Salvia microphylla $(500 \mu \mathrm{g} / \mathrm{ml}) \mathrm{dem}-$ onstrated $52.5 \%$ and $65.0 \%$ Spodoptera frugiperda larval mortality, respectively (Romo-asunción et al., 2016); Zanthoxylum armatum showed strong larvicidal properties against S. litura (Kaleeswaran et al., 2018); Solanum pseudocapsicum seeds extract showed $75.3 \%$ S. litura larval mortality; Strychnos nuxvomica (88.98\%), Vitex negundo (86.41\%), Murraya koenigii (81.46\%), Zanthoxylum limonella (80.58\%) and Abrus precatorius (78.61\%) crude extracts showed larvicidal activity against $S$. litura larvae.

Senthil-Nathan et al. (2008) reported dose-dependent mortality was a common phenomenon, which was emphasized in this study. It was noticed that $C$. dactylon crude extract at $1.45 \mu \mathrm{g} / \mathrm{ml}$ reduced $S$. litura larval population to $50 \%$, dose-dependent responses depend upon the concentration of the active ingredient, as well as the mixture of chemicals (Dinesh-Kumar et al., 2018). Lethal concentrations or doses $\left(\mathrm{LC}_{50}\right.$ or $\left.\mathrm{LD}_{50}\right)$ were estimated from S. nodiflora-0.003 $\mu \mathrm{g} / \mathrm{ml}$ (Rathi \& Gopalakrishnan, 2006), A. archangelica-0.32 $\mu \mathrm{g} / \mathrm{ml}$ (Pavela \& Vrchotová, 2013), Swietenia mahagoni-31.04 $\mu \mathrm{g} / \mathrm{ml}$ (Dinesh-Kumar et al., 2018) and Casimiroa edulis - $79.47 \mu \mathrm{g} / \mathrm{ml}$ (Barakat, 2011) against Spodoptera species.

\section{Conclusion}

The crude extracts are easy to prepare and handle in comparison to commercially available chemical insecticides. The present investigation showed the amicable solution for the management of S. litura using C. dactylon crude extract. Further, the development of a stable and consistent product from $C$. dactylon crude extract may provide a low cost and eco-friendly approach to manage the S. litura.

\section{Abbreviations \\ USD: United States Dollars; IPM: Integrated Pest Management; SPSS: Statisti- cal Package for Social Sciences; EtoAc: Ethyl acetate; MeOH: Methanol; $\mu$ g: Microgram; ANOVA: Analysis of variance; $\mu \mathrm{g} / \mathrm{ml}$ : Micrograms per milliliter; $L_{50}$ : Lethal concentration; LD $_{50}$ : Lethal dose. \\ Acknowledgements \\ Authors are thankful to the Crop Protection division, Indian Council for Agricultural Research —Indian Institute of Pulses Research for providing the facilities to experiment.}

\section{Authors' contributions}

All authors have read and approved the manuscript. DS conducted the experiment and analyzed the data; KGB designed and drafted the manuscript.

\section{Funding}

Not applicable.
Availability of data and materials

Not applicable.

\section{Declarations}

Ethics approval and consent to participate

Not applicable.

\section{Consent for publication}

Consent was taken from the competent authority.

\section{Competing interests}

Authors declare that there was no conflict of interest.

\section{Author details}

${ }^{1}$ Entomology Department, Chaudhary Charan Singh University, Meerut, U.P., India. ${ }^{2}$ Division of Crop Protection, ICAR-Indian Institute of Pulses Research, Kanpur, U.P., India.

Received: 31 March 2021 Accepted: 11 February 2022

Published online: 03 March 2022

\section{References}

Almosnid, M. N., Zhou, X., Jiang, L., Ridings, A., Knott, D., Wang, S., Wei, F., Yuan, J., Altman, E., Gao, Y., \& Miao, J. (2018). Evaluation of extracts prepared from 16 plants used in Yao ethnomedicine as potential anticancer agents. Journal of Ethnopharmacology, 211, 221-234.

Arivoli, S., \& Tennyson, S. (2013). Antifeedant activity, developmental indices and morphogenetic variations of plant extracts against Spodoptera litura (Fab) (Lepidoptera: Noctuidae). Journal of Entomology and Zoology Studies, 1(4), 87-96.

Ashokaraj, S. K., \& Mahadev, C. K. (2012). Study on larvicidal activity of weed extracts against Spodoptera litura. Journal of Environmental Biology., 34, 253-257.

Atwal, A. S., \& Dhaliwal, G. S. (2009). Agricultural pests of South Asia and their management. Kalyani Publishers.

Babu, B. C., Sharma, H., Madhumati, T., Raghavaiah, G. V., Murthy, K. V., \& Rao, V. S. (2014). A semi-synthetic chickpea flour based diet for long-term maintenance of laboratory culture of Helicoverpa armigera. Indian Journal of Entomology, 76, 336-340.

Bagalkotkar, G., Sagineedu, S. R., Saad, M. S., \& Stanslas, J. (2006). Phytochemical from Phyllanthus niruri Linn. and their pharmacological properties: A review. Journal of Pharmacy and Pharmacology, 58, 1559-1570.

Bañez, S. E., \& Castor, L. A. (2011). Phytochemical and Pesticidal Properties of Barsanga (Cyperus rotundus Linn.). JPAIR Multidisciplinary Research, 1, 1-1.

Bapatla, K. G., Kumar, K., Kumar, L., Singh, B., \& Singh, N. P. (2021). Anti-larval activity of actinobacterial extract for Helicoverpa armigera and Spodoptera litura. International Journal of Tropical Insect Science. https://doi.org/10. 1007/s42690-021-00565-w

Barakat, D. (2011). Insecticidal and antifeedant activities and chemical composition of Casimiroa edulis La Llave \& Lex (Rutaceae) leaf extract and its fractions against Spodoptera littoralis larvae. Australian Journal of Basic and Applied Sciences, 5, 693-703.

Bermúdez, T. K., Martínez Herrera, J., Figueroa Brito, R., et al. (2009). Activity of quinolizidine alkaloids from three Mexican Lupinus against the lepidopteran crop pest Spodoptera frugiperda. BioControl, 54, 459-466.

Biswas, T. K., \& Mukherjee, B. (2003). Plant medicines of Indian origin for wound healing activity. The International Journal of Lower Extremity Wounds, 2 , 25-39.

Dang Hoa, T., Takagi, M., \& Ueno, T. (2017). Efficacy of the extract from pongam leaves (Pongamia pinnata L.) against Spodoptera exigua (Hubner) and Spodoptera litura Fabricius (Lepidoptera: Noctuidae). Journal of the Faculty of Agriculture, Kyushu Univesity, 62, 439-443.

Dhaliwal, G. S., \& Koul, O. (2010). Quest for pest management: From green revolution to gene revolution. Kalyani Publishers.

Dhar, M. L., Dhar, M. M., Dhawan, B. N., \& Ray, C. (1968). Screening of Indian plants for biological activity. Part I. Indian Journal of Experimental Biology, 6, 232-247. 
Dinesh-Kumar, A., Srimaan, E., Chellappandian, M., et al. (2018). Target and non-target response of Swietenia Mahagoni Jacq. chemical constituents against tobacco cutworm Spodoptera litura Fab. and earthworm, Eudrilus Eugeniae Kinb. Chemosphere, 199, 118-130.

Edwin, E., Vasantha-Srinivasan, P., Senthil-Nathan, S., et al. (2016). Anti-dengue efficacy of bioactive andrographolide from Andrographis paniculata (Lamiales: Acanthaceae) against the primary dengue vector Aedes aegypti (Diptera: Culicidae). Acta Tropica, 163, 167.

Ewete, F. K., Arnason, J. T., Larson, J., \& Philogene, B. J. R. (1996). Biological activities of extracts from traditionally used Nigerian plants against the European corn borer, Ostrinia nubilalis. Entomologia Experimentalis Et Applicata, 80, 531-537.

Gandhi, K., Patil, R. H., \& Srujana, Y. (2016). Field resistance of Spodoptera litura (Fab.) to conventional insecticides in India. Crop Protection, 88, 103-108.

Garad, G. P., Shivapuje, P. R., \& Bilapate, G. G. (1984). Life fecundity tables of Spodoptera litura (F.) on different hosts. Proceedings: Indian Academic Sciences, 93, 29-33.

George, S., Basilios, P., Christos, D. G., \& Nikos, A. G. (1997). An extreme temperature protector of phosphoenolpyruvate carboxylase from the C4-plant Cynodon dactylon. Phytochemistry, 46, 1331.

Huang, L., Chen, S., \& Yang, M. (2012). Euphorbia hirta (Feiyangcao): A review on its ethnopharmacology, phytochemistry and pharmacology. Journal of Medicinal Plant Research, 6, 5176-5185.

IBM Corp. (2017). IBM SPSS Statistics for Windows, Version 25.0. Armonk, New York.

Islam, M. S., \& Talukder, F. A. (2005). Toxic and residual effects of Azadirachta indica, Tagetes erecta and Cynodon dactylon seed extracts and leaf powders towards Tribolium castaneum. Journal of Plant Diseases and Protection $112,594-601$.

Jeyasankar, P., \& Elumalai, K. (2012). Biological activities of Solanum pseudocapsicum (Solanaceae) against cotton bollworm, Helicoverpa armigera (Hübner) and armyworm, Spodoptera litura (Fabricius) (Lepidoptera: Noctuidae). Asian Pacific Journal of Tropical Biomedicine, 2, 981-986.

Kaleeswaran, G., Firake, D. M., Sanjukta, R., Behere, G. T., \& Ngachan, S. V. (2018). Bamboo-Leaf Prickly Ash extract: A potential bio-pesticide against oriental leaf worm, Spodoptera litura (Fabricius) (Lepidoptera: Noctuidae). Journal of Environmental Management, 208, 46-55.

Kao, S. H., Su, S. N., Huang, S. W., Tsai, J. J., \& Chow, L. P. (2005). Subproteome analysis of novel lgE- binding proteins from Bermuda grass pollen. Proteomics, 5, 3805

Kumar, A., Negi, N., Haider, S. Z., \& Devendra, N. (2014). Composition and efficacy of Zanthoxylum alatum essential oils and extracts against Spodoptera litura. Chemistry of Natural Compounds, 50(5), 920-923.

Lim, Y., \& Murtijaya, J. (2007). Antioxidant properties of Phyllanthus amarus extract as affected by different drying methods. Food Science and Technology, 40, 1664-1669.

Lopez, F. (1903). Experimental study of hydrocyanic acid as an insecticide. Public Health Papers and Reports., 29, 214-220.

Micheal, R. M., Luis, J. G., \& Patricia, T. (1997). Bacteria: Bioassay of Bacillus thuringiensis against lepidopteran larvae. In: Manual of Techniques in Insect Pathology. Edited by Lawrence A.L. USA. Academic Press (p. 97).

Nagarajan, M., Kuruvilla, G. R., Kumar, K. S., \& Venkatasubramanian, P. (2015). Abhava pratinidhi dravya A comparative phytochemistry of Ativisha, Musta and related species. Journal of Ayurveda and Integrative Medicine, 6,53-63.

Nalamolu, R. K., Boini, K. M., \& Nammi, S. (2004). Effect of chronic administration of Boerhaavia diffusa Linn. leaf extract on experimental diabetes in rats. Tropical Journal of Pharmaceutical Research, 3(1), 305-309.

Pavela, R., \& Vrchotová, N. (2013). Insecticidal effect of furanocoumarins from fruits of Angelica archangelica L. against larvae Spodoptera littoralis Boisd. Industrial Crops and Products, 43, 33-39.

Raghu, J. D., Veerashekar, T., Kuppast, I. J., Dharshan, S., \& Ravi, M. C. (2014). A review on Parthenium hysterophorus Linn. International Journal of Pharma and Bio Sciences, 3, 110-120.

Rajput, S., Tara, J. S., \& Langer, S. (2018). Bioefficacy of leaf extracts of two medicinal plants Vitex negundo and Justicia adhatoda against third instar larvae of Spodoptera litura (Fab) (Lepidoptera: Noctuidae). International Journal of Research and Analytical Reviews, 5(4), 352-362.

Rathi, J. M., \& Gopalakrishnan, S. (2006). Insecticidal activity of aerial parts of Synedrella nodiflora Gaertn (Compositae) on Spodoptera litura (Fab.). Journal of Central European Agriculture, 6(3), 223-228.
Romo-asunción, D., Ávila-Calderón, M. A., Ramos-López, M. A., et al. (2016). Juvenomimetic and insecticidal activities of Senecio salignus (Asteraceae) and Salvia microphylla (Lamiaceae) on Spodoptera frugiperda (Lepidoptera: Noctuidae). The Florida Entomologist, 99, 345-351.

Santhi, R., \& Annapoorani, S. (2010). Efficacy of Cynodon dactylon for immunomodulatory activity. Drug Invention Today, 2, 112-114.

Senthil-Nathan, S. (2013). Physiological and biochemical effect of Neem and other Meliaceae plants secondary metabolites against Lepidopteran insects. Frontiers in Physiology, 4, 1-17.

Senthil-Nathan, S., Choi, M. Y., Seo, H. Y., Paik, C. H., Kalaivani, K., \& Kim, J. D. (2008). Effect of azadirachtin on acetylcholinesterase (AChE) activity and histology of the brown plant hopper Nilaparvata lugens (Stal). Ecotoxicology and Environmental Safety, 70, 244-250.

Talukder, F. A., \& Howse, P. E. (1995). Evaluation of Aphanamixis polystachya as repellants, antifeedants, toxicants and protectants in storage against Tribolium castaneum (Herbst). Journal of Stored Products Research, 31, 55-61.

Talukder, F. A., \& Miyata, T. (2002). In vivo and in vitro toxicities of pithraj and neem against rice green leafhopper (Nephotettix cincticeps Uhler). Z. Pflanzenkrankh. Pflanzensch. Journal of Plant Diseases and Protection, 109, 543-550.

Thodsare, N., Bhatt, P., \& Srivastava, R. (2014). Bioefficacy of Murraya koenigii oil against Spilosoma obliqua and Spodoptera litura. Journal of Entomology and Zoology Studies, 2, 201-205.

Vasantha-Srinivasan, P., Senthil-Nathan, S., Ponsankar, A., et al. (2017). Comparative analysis of mosquito (Diptera: Culicidae: Aedes aegypti Liston) responses to the insecticide Temephos and plant derived essential oil derived from Piper beetle L. Ecotoxicology and Environmental Safety, 139, 439-446.

Zandi-Sohani, N., \& Ramezani, L. (2015). Evaluation of five essential oils as botanical acaricides against the strawberry spider mite Tetranychus turkestani Ugarov and Nikolskii. International Biodeterioration and Biodegradation, 98, 101-106.

\section{Publisher's Note}

Springer Nature remains neutral with regard to jurisdictional claims in published maps and institutional affiliations.

\section{Submit your manuscript to a SpringerOpen ${ }^{\odot}$ journal and benefit from:}

- Convenient online submission

- Rigorous peer review

- Open access: articles freely available online

- High visibility within the field

- Retaining the copyright to your article

Submit your next manuscript at $\mathbf{s p r i n g e r o p e n . c o m ~}$ 